\section{Physiological disorder of plants depending on clopyralid concentration in the soil and plant}

\author{
Sayuri Namiki, * Nobuyasu SeIKe and \\ Eiki WATANABE \\ Institute for Agro-Environmental Sciences, NARO, \\ 3-1-3 Kannondai, Tsukuba, Ibaraki 305-8604, Japan
}

(Received January 9, 2019; Accepted February 24, 2019)

The influence of clopyralid in soil on plant growth was investigated over time using three plants. The order of clopyralid sensitivity was as follows: Solanum lycopersicum $>$ Solanum melongena $>$ Momordica charantia, especially physiological disorder of $S$. lycopersicum were rapidly expressed as various serious symptoms with increasing concentration of clopyralid. In contrast, the clopyralid concentration of above-ground part was in the following order: $M$. charantia $>$ S. lycopersicum, S. melongena, which differed from the order of sensitivity to clopyralid. (๑) Pesticide Science Society of Japan

Keywords: clopyralid, synthetic auxin, physiological disorder, aboveground plant concentration.

\section{Introduction}

Clopyralid (3,6-dichloro-2-pyridinecarboxylic acid), which is a growth regulator herbicide, is widely used for weed control in the cultivation of cereal and grass in the USA, Canada, and Australia, among other regions, although it is not used in Japan. ${ }^{1)}$ It is discharged in the excrement of livestock that have eaten feed containing it. Because clopyralid is hardly degraded, ${ }^{2)}$ it remains in the compost produced from this excrement. Indeed, it has been reported that crops were damaged by the application of compost with residual clopyralid. ${ }^{3-5)}$ Although clopyralid is not registered for use in Japan, exposure to it has occurred in the country via compost made from the excrement of livestock that have eaten imported feed containing clopyralid. ${ }^{6,7)}$ Thus, crop damage caused by compost with residual clopyralid has become a problem in Japanese agriculture. ${ }^{8)}$

The sensitivity to clopyralid differs among plant species; Solanaceae, Fabaceae, and Asteraceae have higher sensitivity to it than other plant families. ${ }^{9)}$ For example, according to Kelley

\footnotetext{
* To whom correspondence should be addressed.

E-mail: namikisayuri@affrc.go.jp

Published online April 7, 2019

(c) Pesticide Science Society of Japan
}

et al., ${ }^{10)}$ the leaves of Glycine max Merrill became cupped and crinkled after clopyralid was sprayed on them. Moreover, when $50 \mu \mathrm{g}$ of clopyralid was applied to the cotyledons, the leaves of Helianthus annuus L. became epinastic after $4 \mathrm{hr}$, and the stem was curved after $8 \mathrm{hr} .{ }^{11)}$ Injury to Solanum tuberosum L. was also observed upon the presence of $3 \mu \mathrm{g} / \mathrm{kg}$-DW clopyralid in soil when this species was cultivated in soil mixed with Mentha cardiaca L. hay that had been treated with clopyralid. ${ }^{12)}$ Damage to Trifolum pratense L. due to clopyralid was also found to be more severe than that to Pisum sativum L. upon their cultivation in compost containing 10 and $50 \mu \mathrm{g} / \mathrm{kg}$-DW clopyralid. ${ }^{13)} \mathrm{Al}-$ though the damage due to clopyralid was investigated in several plant species having high sensitivity to that herbicide, ${ }^{14)}$ there are few reports on the influence of clopyralid concentration in soil on the time-dependent shoot morphogenesis in plants having different sensitivities to it. The concentrations of clopyralid in plants were investigated for plants that are relatively tolerant to it, such as Secale cereale L. ${ }^{15)}$ and Brassicaceae. ${ }^{16)}$ In contrast, the concentrations of clopyralid in clopyralid-sensitive plants such as Solanaceae remain unclear.

Against that background, this study was performed to determine the influence of clopyralid concentration in soil over time on physiological disorders in the initial growth of plants such as S. lycopersicum, Solanum melongena L., and Momordica charantia L. which differ in their sensitivity to clopyralid and have been reported to suffer damage by it in Japan. ${ }^{17)}$ In addition, the sensitivity of these plants to clopyralid was evaluated using the physiological disorder and biomass of above-ground part, followed by discussion of the relationship of these variables to the clopyralid concentration in the above-ground part.

\section{Materials and Methods}

\section{Plant culture in test soil}

Clopyralid (chemical purity 98.0\%; Fujifilm Wako Pure Chemical, Osaka, Japan) was dissolved in acetone. This clopyralid solution was then added to uncontaminated compost, after which the acetone was evaporated at room temperature in a draft chamber. In the results obtained in the survey of compost, the concentrations of clopyralid in compost were the mean value of $23 \mu \mathrm{g} / \mathrm{kg}-\mathrm{DW}$ in the range of $<0.1$ to $380 \mu \mathrm{g} / \mathrm{kg}-\mathrm{DW}$. $^{7)}$ When these composts are added to soil at 1 ton per 10 are, and suppose that plow layer is $10 \mathrm{~cm}$, the concentrations of clopyralid in soil is $10 \mathrm{~cm}$ are the mean value of $0.23 \mu \mathrm{g} / \mathrm{kg}-\mathrm{DW}$ and the maximum value of $3.8 \mu \mathrm{g} / \mathrm{kg}$-DW. Thus, the final concentrations of clopyralid in the compost were $0,100,500$, and 2,500 $\mu \mathrm{g} / \mathrm{kg}$-DW. This compost was added to uncontaminated nursery soil (Nihon Hiryo Co., Ltd., Tokyo, Japan) and the final concentrations of clopyralid in the soil were $0,1,5$, and $25 \mu \mathrm{g} / \mathrm{kg}$-DW.

Plastic pots $(500 \mathrm{~mL})$ were filled with this prepared soil $(297 \mathrm{~g}$ of nursery soil mixed with $3 \mathrm{~g}$ of prepared compost). We pre- 
pared the soil 1 day before transplanting the seedlings and placed the plastic pots in the dark in plant-cultivation conditions. Seeds of S. lycopersicum 'Aiko' (Sakata Seed Corp., Yokohama, Japan) and 'Chika' (Takii \& Co., Ltd., Kyoto, Japan), S. melongena 'Senryou-2-gou' and 'Chikuyou' (Takii \& Co., Ltd.), and M. charantia 'Abashi-goya' (Sakata Seed Corp.) were sown in nursery soil and germinated in a growth chamber (Koito Kogyo, Kanagawa, Japan) at $25: 20^{\circ} \mathrm{C}$ for S. lycopersicum and S. melongena, and $25^{\circ} \mathrm{C}$ for $M$. charantia under a $12: 12 \mathrm{hr}$ light: dark cycle. At 14 days for S. lycopersicum and S. melongena, and at 10 days for $M$. charantia, the seedlings were transplanted into pots and raised under the same conditions as in germination for 28 days. We supplied water from the bottom of the pot to prevent the runoff of clopyralid, and the soil moisture was maintained at $60-80 \%$ water-holding capacity. Every 7 days after transplanting, we observed the morphology of the aboveground part. Twenty-eight days after transplanting, the aboveground parts were harvested. The fresh weights of the aboveground parts were measured for each sample and then cut finely, mixed, and divided into two subsamples. One subsample was dried at $70^{\circ} \mathrm{C}$ to measure the moisture content, and the other was used to measure the clopyralid content. These uptake experiments were conducted in quadruplicate.

\section{Analysis of clopyralid concentration in plants}

To extract clopyralid, $10 \mathrm{~g}$ of above-ground plant samples were homogenized with $125 \mathrm{~mL}$ of methanol:1 M NaOH (99:1) for $3 \mathrm{~min}$. The extract was passed through a $0.8 \mu \mathrm{m}$ glass-fiber filter and concentrated to $100 \mathrm{~mL}$ in a rotary evaporator. Ten milliliters of extract was washed through a solid-phase extraction cartridge (Oasis HLB $225 \mathrm{mg}$, Waters, Milford, MA, USA) and eluted with $10 \mathrm{~mL}$ of methanol: $0.01 \mathrm{M} \mathrm{NaOH}(1: 1)$. The eluate was concentrated to $5 \mathrm{~mL}$ in a rotary evaporator and then supplemented with $3 \mathrm{~mL}$ of $1 \mathrm{M} \mathrm{HCl}$. The concentrated solution was washed through a solid-phase extraction cartridge (Oasis HLB $225 \mathrm{mg}$ ) with $10 \mathrm{~mL}$ of $0.1 \mathrm{M} \mathrm{HCl}$ and then washed with $5 \mathrm{~mL}$ of $0.1 \mathrm{M} \mathrm{HCl}$ : acetonitrile $(9: 1)$ and $5 \mathrm{~mL}$ of water, followed by elution with $4 \mathrm{~mL}$ of $0.0028 \%(\mathrm{w} / \mathrm{v})$ ammonia water:acetonitrile $(9: 1)$. The eluate that was supplemented with $100 \mu \mathrm{L}$ of $1 \mathrm{M}$ $\mathrm{NaOH}$ was extracted twice with $2 \mathrm{~mL}$ of dichloromethane with shaking for $30 \mathrm{sec}$, followed by centrifugation at $740 \times g$ for $1 \mathrm{~min}$ and removal of the organic phase. The aqueous phase that was supplemented with $150 \mu \mathrm{L}$ of $12 \mathrm{M} \mathrm{H}_{2} \mathrm{SO}_{4}$ was extracted three times with $2 \mathrm{~mL}$ of dichloromethane with shaking for $30 \mathrm{sec}$, followed by centrifugation at $740 \times g$ for $1 \mathrm{~min}$, after which the extract was collected. The extract was then supplemented with $1 \mathrm{~mL}$ of $n$-hexane and passed through $\mathrm{Na}_{2} \mathrm{SO}_{4}$ for dehydration, followed by drying under a nitrogen stream. Next, the dried residue was dissolved in $200 \mu \mathrm{L}$ of $0.1 \%$ formic acid by ultrasonication for $30 \mathrm{sec}$. The solution was subsequently centrifuged at $1,700 \times g$ for $1 \mathrm{~min}$ and passed through a $0.22-\mu \mathrm{m}$ PVDF membrane. The clopyralid in the cleaned-up samples was measured by liquid chromatography-tandem mass spectrometry (LC-MS/ MS, ACQUITY UPLC-Quattro Micro API, Waters) with an
ACQUITY UPLC HSS TS $(50 \mathrm{~mm} \times \phi 2.1 \mathrm{~mm}, 1.8 \mu \mathrm{m}$ particle size; Waters). The limits of quantification (LOQs) for clopyralid analysis were calculated in accordance with Japanese Industrial Standard (JIS) K 0312. ${ }^{18)}$ The LOQ of clopyralid in above-ground plant samples was $5 \mu \mathrm{g} / \mathrm{kg}$-DW calculated from tenfold standard deviation obtained from 7 times analysis (from extraction to LC-MS/MS measurement). Clopyralid recovery tests were performed on pulverized samples of $S$. lycopersicum above-ground parts in triplicate, spiked at 10 and $250 \mu \mathrm{g} / \mathrm{kg}$-DW. The recovery rate of clopyralid ranged from 97.6 to $116.5 \%$ for $10 \mu \mathrm{g} / \mathrm{kg}-\mathrm{DW}$ and from 92.6 to $104.4 \%$ for $250 \mu \mathrm{g} / \mathrm{kg}$-DW. Performance of the analytical method was described in Watanabe et al. ${ }^{19)}$

\section{Statistical analyses}

Statistical analyses were performed using SPSS 23 software (SPSS Inc., Chicago, IL, USA). Analysis of variance (ANOVA) was performed followed by Dunnett's test for multiple comparisons to $0 \mu \mathrm{g} / \mathrm{kg}$-DW or Tukey's multiple comparison test using a pairwise comparison matrix to determine which samples differed significantly.

\section{Results and Discussion}

We analyzed the relationship between the temporal expression of physiological disorders due to clopyralid in S. lycopersicum 'Aiko,' which was classified as a species with high sensitivity to clopyralid, and the concentrations of clopyralid in soil which were $0,1,5$, and $25 \mu \mathrm{g} / \mathrm{kg}$-DW (Fig. 1).

In $S$. lycopersicum cultivated in soil with $1 \mu \mathrm{g} / \mathrm{kg}$-DW clopyralid, the edges of the upper leaves tended to harden beginning on the 21st day after transplanting (Fig. 1D), and the morphology of flowers and fruits indicated no developmental dysfunction in this experiment. However, in S. lycopersicum cultivated in soil with $5 \mu \mathrm{g} / \mathrm{kg}$-DW clopyralid, the growth point was twisted on the seventh day after transplanting (Fig. 1B); subsequently, rugose leaves and tortuous rachis were observed from the 14th day after transplanting (Fig. 1C). In contrast, the morphology of flowers (Fig. 1E), such as their petals and sepals, indicated no developmental dysfunction. However, because the ovary was enlarged immediately after flowering, it was highly possible that the fruit was parthenocarpic. On the 28th day after transplanting, the fruit of plants grown with $5 \mu \mathrm{g} / \mathrm{kg}$-DW clopyralid showed the deformity of being elongated compared to the fruit of those grown in soil without clopyralid (Fig. 1F). In S. lycopersicum cultivated in soil with $25 \mu \mathrm{g} / \mathrm{kg}$-DW clopyralid, the growth point of the leaves exhibited difficulty developing from the third day after transplanting (Fig. 1A) and then showed a twisted deformity on the seventh day (Fig. 1B). Solanum lycopersicum has compound leaves composed of a number of leaflets. The leaflets and blades in the leaves higher than the fifth leaf could not develop properly, and these leaves developed remarkable abnormalities in soil with $25 \mu \mathrm{g} / \mathrm{kg}$-DW clopyralid (Fig. 1C). The deformed leaves were those that differentiated after transplanting, so it was assumed that they were strongly influenced by clopyralid. On the 21st day after transplanting, the tissue of these de- 

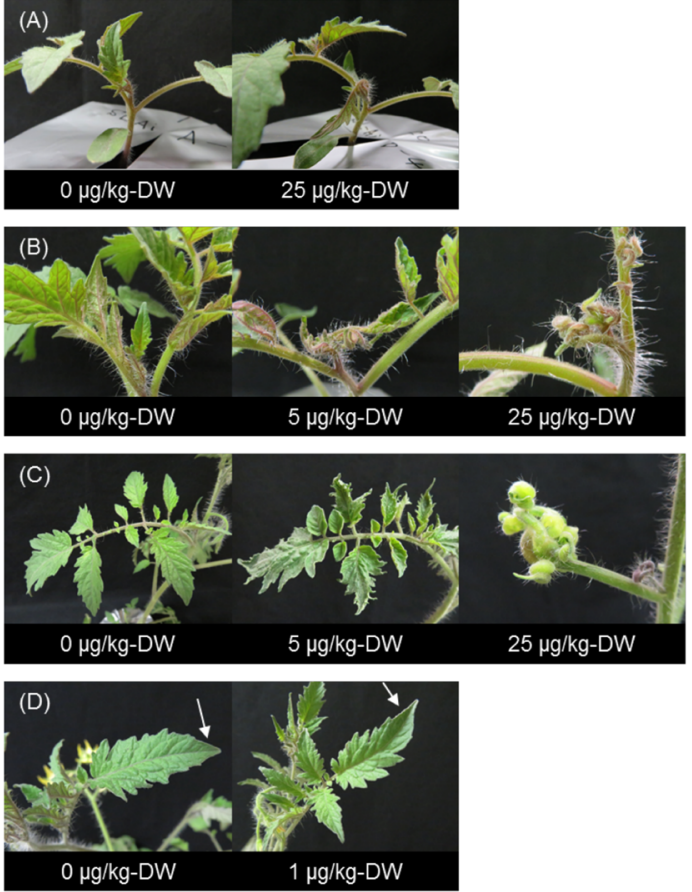
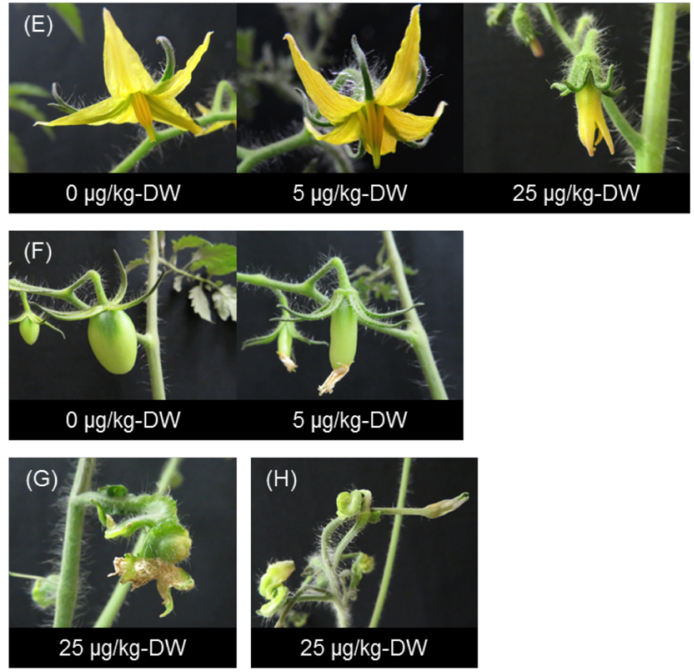

Fig. 1. The physiological disorder in S. lycopersicum 'Aiko' depending on the concentration of clopyralid in the soil. (A) Growth point of the leaves on the 3rd day after transplanting. (B) Growth point of the leaves on the 7th day. (C) Leaves on the 14th day. (D) The upper leaves on the 21 st day. Arrows indicate the leaf edges. (E) Flowers. (F) Fruits. (G) Necrotic leaf. (H) Growth point of leaves on the 21 st day grown with $25 \mu \mathrm{g} / \mathrm{kg}-\mathrm{DW}$ clopyralid in the soil.

formed leaves developed partial necrosis (Fig. 1G), and in one plant, growth stopped altogether (Fig. $1 \mathrm{H}$ ). The flowers did not bloom because they did not develop normally, with the petals and sepals being transformed into tubular structures (Fig. 1E). Additionally, in some plants, flower clusters did not develop properly.

Overall, the findings showed that the period when symptoms of physiological disorders appeared in S. lycopersicum 'Aiko' became earlier with increasing concentrations of clopyralid in the soil. In addition, the physiological disorders were rapidly expressed in the form of various serious injuries with increasing concentrations of clopyralid in the soil. The concentration gradient of auxin controls leaflet initiation in plants exhibiting compound leaves, such as S. lycopersicum. ${ }^{20)}$ Moreover, forms of synthetic auxin, such as clopyralid, bind to auxin receptors and then activate the transcription of auxin-responsive genes. ${ }^{21)}$ This results in the abnormal development of compound leaves and fruit that is controlled by the auxin concentration gradient. Therefore, it was inferred that various serious symptoms, such as rugose leaves and parthenocarpy, were expressed with increasing concentrations of clopyralid in the soil.

Clopyralid sensitivity and the influence of clopyralid concentration in the soil on initial growth were evaluated using morphological observation (Fig. 2A) and by determining the dry weight of the above-ground part of each plant (Fig. 2B). The images of S. lycopersicum 'Aiko' and 'Chika' and S. melongena 'Senryou-2-gou' and 'Chikuyou' are from the 21st day after transplanting, while the images of $M$. charantia 'Abashi-goya' are from the 14th day after transplanting (Fig. 2A).

At $1 \mu \mathrm{g} / \mathrm{kg}-\mathrm{DW}$ clopyralid in soil, abnormal morphology of the above-ground part was not observed in any of the $S$. melongena and $M$. charantia samples, and it was suggested that clopyralid at $1 \mu \mathrm{g} / \mathrm{kg}$-DW in soil did not negatively affect initial growth in these plants. Although the dry weight of the aboveground part of S. lycopersicum did not significantly decrease, the edges of the upper leaves tended to harden in S. lycopersicum at $1 \mu \mathrm{g} / \mathrm{kg}$-DW clopyralid in the soil. On the other hand, $5 \mu \mathrm{g} /$ kg-DW clopyralid in the soil led to remarkable abnormalities of the above-ground plant morphology in S. lycopersicum, such as rugose leaves and tortuous rachis. In addition, the above-ground plant dry weight of $S$. lycopersicum decreased in association with $5 \mu \mathrm{g} / \mathrm{kg}$-DW clopyralid in the soil, so it was concluded that the initial growth of $S$. lycopersicum is inhibited under these conditions. In S. melongena, slight waving or hardening of the leaf edges due to $5 \mu \mathrm{g} / \mathrm{kg}$-DW clopyralid in the soil was observed. However, no abnormal development of leaves or decrease in the above-ground plant dry weight occurred in this species. Thus, the physiological disorder in $S$. melongena was not as severe as in $S$. lycopersicum upon exposure to $5 \mu \mathrm{g} / \mathrm{kg}$-DW clopyralid in the soil. In contrast to the findings for S. lycopersicum and $S$. melongena, the above-ground plant morphology and dry weight of $M$. charantia were not affected by $5 \mu \mathrm{g} / \mathrm{kg}$-DW clopyralid in the soil. At $25 \mu \mathrm{g} / \mathrm{kg}$-DW clopyralid in soil, S. lycopersicum showed severely rugose leaves, and its leaflets and blades could not develop properly. In addition, the growth point of S. lycopersicum became deformed and partially necrotic, after which 

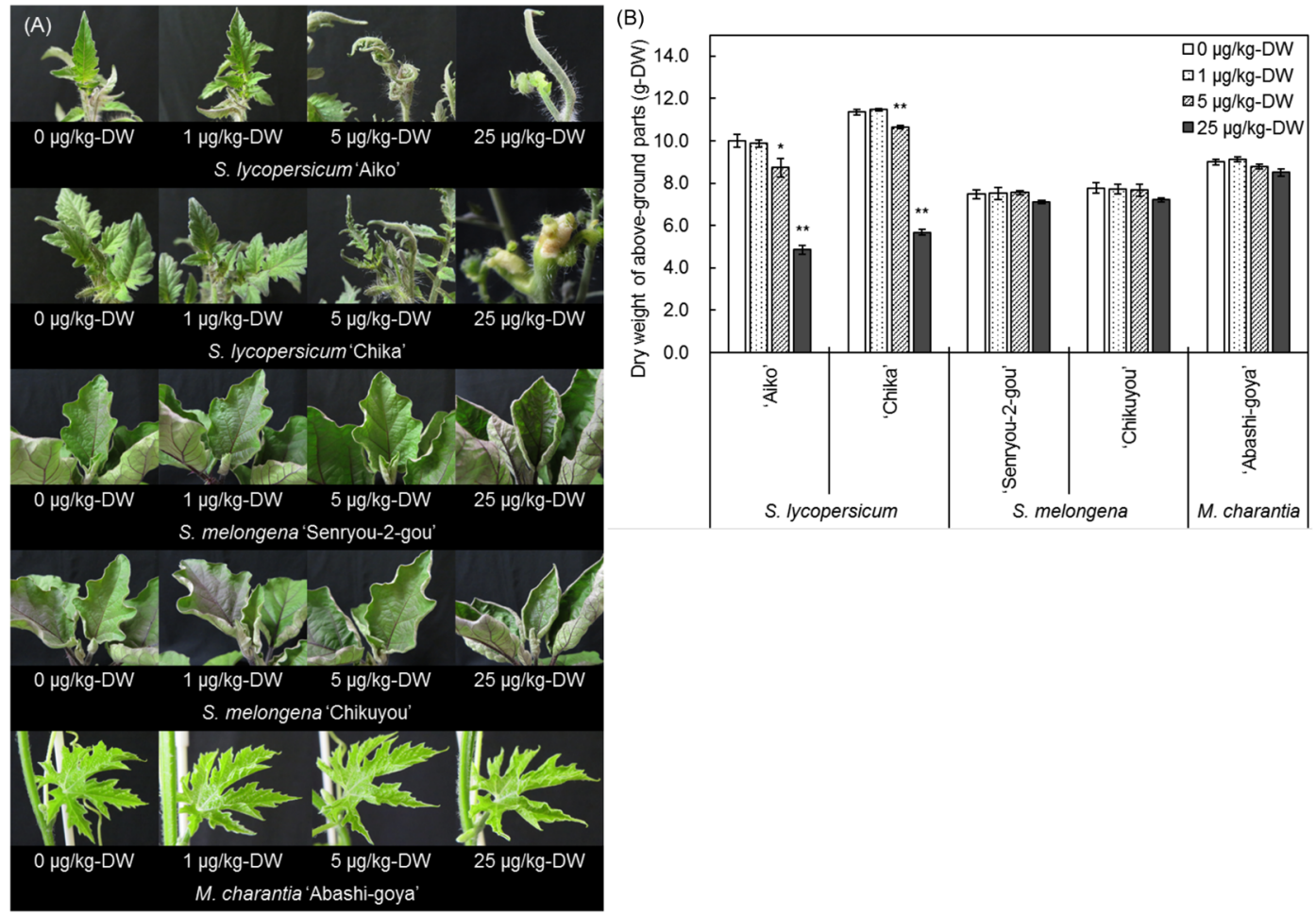

Fig. 2. The sensitivity to clopyralid in each plant species depending on its concentration in the soil. (A) The physiological disorder in each plant. Images of S. lycopersicum and S. melongena are from the 21st day after transplanting, while those of M. charantia are from the 14th day after transplanting. (B) Dry weights of above-ground parts of plants 28 days after the start of treatment. Data were analyzed by one-way ANOVA, followed by Dunnett's test for multiple comparisons to $0 \mu \mathrm{g} / \mathrm{kg}$-DW $(* p<0.05, * * p<0.01)$.

growth stopped. Moreover, the above-ground plant dry weight of S. lycopersicum with $25 \mu \mathrm{g} / \mathrm{kg}$-DW clopyralid decreased to approximately half that with $0 \mu \mathrm{g} / \mathrm{kg}$-DW clopyralid in the soil. Therefore, it was determined that the presence of clopyralid at $25 \mu \mathrm{g} / \mathrm{kg}$-DW in soil markedly affects the initial growth of $S$. $l y$ copersicum. In $S$. melongena, the leaves exhibited cupping, and the above-ground plant dry weight also tended to decrease with $25 \mu \mathrm{g} / \mathrm{kg}$-DW clopyralid in the soil. In contrast, although unexpanded leaves were slightly tortuous at 14 days after transplanting into the soil, $M$. charantia was generally not influenced by $25 \mu \mathrm{g} / \mathrm{kg}$-DW clopyralid in the soil, since its leaves exhibited normal development thereafter.

These results indicate that the sensitivity of plants to clopyral- id is in the following order: $S$. lycopersicum $>$ S. melongena $>M$. charantia. It was concluded that the clopyralid concentrations in soil that can cause serious physiological disorders, such as specifically inhibiting initial growth, are more than $5 \mu \mathrm{g} / \mathrm{kg}$-DW for S. lycopersicum and $25 \mu \mathrm{g} / \mathrm{kg}$-DW for S. melongena. In addition, it is possible that the difference in sensitivity to clopyralid between S. lycopersicum and S. melongena, despite their both being from the Solanaceae family, is caused by their differences in leaf formation. Because the control of plant hormones involved in leaf initiation differs between S. lycopersicum, which has compound leaves, and $S$. melongena, which has single leaves, ${ }^{22)}$ it was assumed that $S$. lycopersicum is more sensitive to clopyralid than S. melongena. Moreover, the affinity for auxin receptors is one

Table 1. Concentration of clopyralid in each above-ground part after 28 days of growth.

\begin{tabular}{lrrr}
\hline \multicolumn{1}{c}{ Plants } & \multicolumn{3}{c}{ Clopyralid concentrations in soil } \\
\cline { 2 - 4 } & $1 \mu \mathrm{g} / \mathrm{kg}-\mathrm{DW}$ & $5 \mu \mathrm{g} / \mathrm{kg}$-DW & $25 \mu \mathrm{g} / \mathrm{kg}-\mathrm{DW}$ \\
\hline Concentrations of clopyralid in above-ground part $(\mu \mathrm{g} / \mathrm{kg}-\mathrm{DW})$ & & & $471.7 \pm 18.6 \mathrm{~B}$ \\
S. lycopersicum 'Aiko' & $5.7 \pm 0.5 \mathrm{~A}$ & $41.2 \pm 6.7 \mathrm{~A}$ & $493.8 \pm 35.2 \mathrm{~B}$ \\
S. lycopersicum 'Chika' & $<5.00^{a)} \mathrm{A}$ & $20.4 \pm 0.6 \mathrm{~A}$ & $210.4 \pm 17.9 \mathrm{~A}$ \\
S. melongena 'Senryou-2-gou' & $5.3 \pm 0.8 \mathrm{~A}$ & $31.6 \pm 2.1 \mathrm{~A}$ & $209.7 \pm 13.7 \mathrm{~A}$ \\
S. melongena 'Chikuyou' & $5.9 \pm 0.3 \mathrm{~A}$ & $29.7 \pm 1.6 \mathrm{~A}$ & $662.2 \pm 16.0 \mathrm{C}$ \\
M. charantia 'Abashi-goya' & $23.6 \pm 0.8 \mathrm{~B}$ & $129.6 \pm 3.5 \mathrm{~B}$ & \\
\hline
\end{tabular}

Mean \pm standard error of the mean $(n=4)$. Data were compared using one-way ANOVA followed by Tukey's multiple comparison test ( $p<0.001$ ). Within a column, means followed by the same letter are not significantly different. ${ }^{a}$ Under the quantification limit. 
of the most important factors determining selectivity in the activation by synthetic auxins such as clopyralid, and plants have several auxin receptors that have different affinities for auxin. ${ }^{23)}$ Therefore, although the auxin receptors that clopyralid has high affinity have unknown, differences in the sensitivity to clopyralid might be caused by the differences in auxin receptors among plant species.

The clopyralid concentrations in the above-ground parts of plants are shown in Table 1. Clopyralid was not detected in the above-ground parts upon cultivation in soil with $0 \mu \mathrm{g} / \mathrm{kg}-\mathrm{DW}$ clopyralid (data not shown), so all of the clopyralid in the aboveground parts was considered to have translocated from the roots.

At $1 \mu \mathrm{g} / \mathrm{kg}$-DW clopyralid in soil, the above-ground plant concentrations of clopyralid in S. lycopersicum and S. melongena were very low, whereas those in $M$. charantia were four times higher than in the other tested plants. In addition, the aboveground plant concentration of clopyralid in M. charantia was about three to six times higher than those in S. lycopersicum and S. melongena at $5 \mu \mathrm{g} / \mathrm{kg}$-DW clopyralid in soil. At $25 \mu \mathrm{g} / \mathrm{kg}$-DW clopyralid in soil, the above-ground plant concentrations of clopyralid in S. melongena were the lowest, those in S. lycopersicum were low, and those in M. charantia were the highest, as in the cases of cultivation with other concentrations of clopyralid in the soil. These results show that the concentrations of clopyralid in above-ground parts of tested plants did not necessarily correspond to the degree of physiological disorder in their above-ground parts.

In general, the uptake of organic chemicals including pesticides such as clopyralid by plants is influenced by the chemicals' properties, especially those that determine the $n$-octanol-water partition coefficient $\left(K_{\mathrm{OW}}\right){ }^{24)}$ According to Dettenmaier et al., ${ }^{25)}$ organic chemicals with a $\log K_{\mathrm{OW}}<0$ have a high ability to translocate from root to shoot. Because the $\log K_{\mathrm{OW}}$ value of clopyralid is $-2.63,{ }^{26)}$ it was assumed that clopyralid can smoothly translocate from the root to the above-ground part of plants by transpiration. In addition, although Cucurbitaceae has a speciesspecific high translocation ability for high hydrophobic chemicals with a $\log K_{\mathrm{OW}}>5$, such as dieldrin, this ability could not be observed in organic chemicals with a $\log K_{\mathrm{OW}}<4 .{ }^{27,28)}$ Therefore, it was inferred that $M$. charantia does not have a species-specific high translocation ability from the root to the above-ground part of the plant for clopyralid. Although S. lycopersicum and $S$. melongena were considered to have taken up clopyralid like $M$. charantia, the concentrations of clopyralid in the above-ground parts of these plants were low. This suggested that these two species might metabolize the clopyralid or accumulate it in the root to prevent transport to the above-ground parts.

In future work, it will be necessary to identify the auxin receptor(s) that has high affinity for clopyralid and the mechanisms of clopyralid metabolism in order to explain the differences in sensitivity and above-ground plant concentration of clopyralid among plant species. In addition, elucidation of the factors behind the differences in response to clopyralid among plant species should contribute to preventing physiological disorders.

\section{Acknowledgements}

This research was partially supported by the Science and Technology Research Promotion Program for Agriculture, Forestry, Fisheries, and Food Industry (29030C) of the Ministry of Agriculture, Forestry and Fisheries, Japan.

\section{References}

1) C. Cox: J. Pestic. Reform 18, 15-19 (1998).

2) R. Ahmad, T. K. James, A. Rahman and P. T. Holland: J. Environ. Sci. Health B 38, 683-695 (2003).

3) M. Fauci, D. F. Bezdic, D. Caldwell and R. Finch: Contam. Toxicol. 68, 79-85 (2002)

4) E. Miltner, A. Bary and C. Cogge: Compost Sci. Util. 11, 289-299 (2003).

5) R. X. Chang, F. C. Michel J., J. J. Gan, Q. Wang and Y. M. Li: Compost Sci. Util. 25, 523-530 (2017).

6) http://www.maff.go.jp/j/seisan/kankyo/clopyralid/attach/pdf/clopy ralid-25.pdf (Accessed 11 Oct. 2018)

7) http://www.maff.go.jp/j/seisan/kankyo/clopyralid/attach/pdf/clopy ralid-33.pdf (Accessed 11 Oct. 2018)

8) T. Sato, K. Yoshida and I. Shigemori: J. Sci. Soil Manure. Jpn. 81, 3206-3217 (2005) (in Japanese).

9) T. C. Blewett, D. W. Roberts and W. F. Brinton: Renew. Agric. Food Syst. 20, 67-72 (2005).

10) K. B. Kelley, L. M. Wax, A. G. Hager and D. E. Riechers: Weed Sci. 53, 101-112 (2005).

11) J. C. Hall, P. K. Bassi, M. S. Spencer and W. H. Vanden Born: Plant Physiol. 79, 18-23 (1985).

12) R. A. Boydston: Weed Technol. 8, 296-298 (1994).

13) W. F. Brinton, E. Evans and T. C. Blewett: Compost Sci. Util. 14, 244251 (2006).

14) J. Felix, D. J. Doohan, S. C. Ditmarsen, M. E. Schultz, T. R. Wright, B. R. Flood and T. L. Rabaey: Crop Prot. 24, 790-797 (2005).

15) O. Sakaliene, S. K. Papiernik, W. C. Koskinen, I. Kaviliūnaite and J. Brazenaitei: J. Agric. Food Chem. 57, 1975-1981 (2009).

16) R. Saito, O. Ikenaga, S. Ishihara, H. Shibata, T. Iwafune, T. Sato and $Y$. Yamashita: J. Pestic. Sci. 35, 479-482 (2010).

17) http://www.maff.go.jp/j/seisan/kankyo/clopyralid/attach/pdf/clopy ralid-41.pdf (Accessed 12 Feb. 2019)

18) Japanese Standards Association: JIS K 0312, Tokyo, Japan (2005) (in Japanese).

19) E. Watanabe, N. Seike and S. Namiki: J. Pestic. Sci. (2019) (Accepted).

20) D. Koenig, E. Bayer, J. Kang, C. Kuhlemeier and N. Sinha: Development 136, 2997-3006 (2009).

21) K. Grossmass: Pest Manag. Sci. 66, 113-120 (2010).

22) E. Shani and S. Hardas Ben-Gera: Plant Cell 22, 3206-3217 (2010).

23) N. Dharmasiri, S. Dharmasiri, D. Weijers, E. Lechner, M. Yamada, L. Hobbie, J. S. Ehrismann, G. Jürgens and M. Estelle: Dev. Cell 9, 109-119 (2005).

24) G. G. Briggs, R. T. Bromilow and A. A. Evans: Pestic. Sci. 13, 495-504 (1982).

25) E. M. Dettenmaier, W. J. Doucette and B. Bugbee: Environ. Sci. Technol. 43, 324-329 (2009).

26) http://sitem.herts.ac.uk/aeru/iupac/ (Accessed 11 Oct. 2018)

27) S. Namiki, T. Otani, Y. Motoki, N. Seike and T. Iwafune: J. Pestic. Sci. 43, 96-107 (2018).

28) S. Namiki, T. Otani, N. Seike and S. Satoh: Environ. Toxicol. Chem. 34, 536-544 (2015). 